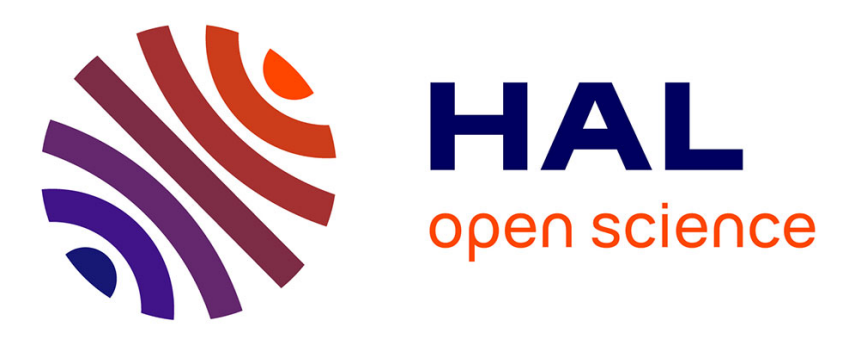

\title{
Energetic and exergetic assessment of solar and wind potentials in Europe
}

Olivier Le Corre, Ibrahim Dincer, Jean-Sébastien Broc

\section{To cite this version:}

Olivier Le Corre, Ibrahim Dincer, Jean-Sébastien Broc. Energetic and exergetic assessment of solar and wind potentials in Europe. Int. J. Exergy, 2013, 13 (2), pp.175-200. 10.1504/IJEX.2013.056132 . hal-00849059

\section{HAL Id: hal-00849059 \\ https://hal.science/hal-00849059}

Submitted on $30 \mathrm{Jul} 2013$

HAL is a multi-disciplinary open access archive for the deposit and dissemination of scientific research documents, whether they are published or not. The documents may come from teaching and research institutions in France or abroad, or from public or private research centers.
L'archive ouverte pluridisciplinaire HAL, est destinée au dépôt et à la diffusion de documents scientifiques de niveau recherche, publiés ou non, émanant des établissements d'enseignement et de recherche français ou étrangers, des laboratoires publics ou privés. 


\section{Energetic and exergetic assessment of solar and wind 2 potential maps in Europe}

\section{Olivier Le Corre*}

Department of Energetics and Environmental Engineering, Ecole des Mines de Nantes,

4 rue A. Kastler, BP 20722,

F-44307 Nantes cedex 3,

France

Olivier.Lecorre@mines-nantes.fr

Corresponding author

\section{Jean-Sébastien Broc}

Department of Energetics and Environmental Engineering,

Ecole des Mines de Nantes,

4 rue A. Kastler, BP 20722,

F-44307 Nantes cedex 3,

France

Jean-sebastien.Broc@mines-nantes.fr

\section{Ibrahim Dincer}

Faculty of Engineering and Applied Science, University of Ontario, Institute of Technology, 2000 Simcoe Street North, Oshawa, Ont., Canada L1H 7K4 Ibrahim.Dincer@uoit.ca

\section{Biographical notes:}

Olivier Le Corre is an Associate Professor of Mechanical Engineering in the Department of Energetics and Environmental Engineering at Ecole des Mines de Nantes. He has authored and co-authored refereed journal and international conferences and taken out numerous patents. He is an active reviewer for international journal.

Jean-Sébastien Broc has a PhD in energy engineering (Mines ParisTech), with a focus on evaluation of energy efficiency activities. He is a research fellow at Ecole des Mines de Nantes. His activities aim at interdisciplinary research about energy issues, crossing engineering and social sciences. He has been the expert nominated by France for the bottom-up working group of the Energy Demand Management Committee (Directive 2006/32/EC), and was also involved in CEN Task Force 190 on the standardization of energy savings calculation. He is reviewer for Energy Efficiency (Springer Ed.) and has been in the scientific committee of two international conferences.

Ibrahim Dincer is a Full Professor of Mechanical Engineering in the Faculty of Engineering and Applied Science at UOIT. Renowned for his pioneering works in the area of sustainable energy technologies, he has authored and co-authored many books and book chapters, refereed journal and conference papers, and technical reports. He has chaired many national and international conferences, symposia, workshops and technical meetings. He has delivered many keynote and invited lectures. He is a recipient of several research, teaching and service awards. 


\section{Abstract}

This paper deals with a physics-based assessment of renewable energy potential in Europe, particularly solar and wind, using two literature models. A sensibility analysis with the weather data is first-done. Actual temperature, pressure, $\mathrm{RH}$, global radiation and wind speed data are employed to develop energy and exergy maps for Europe, based on iso-area of land-use. These maps are compared with similar existing ones. Good agreement is obtained. A paradoxical result is obtained for wind exergy efficiency. The yearly average exergy efficiency where wind speed is less than $5 \mathrm{~m} / \mathrm{s}$ is greater than the one where wind speed is greater than $7 \mathrm{~m} / \mathrm{s}$. This can be explained by the "dome" shape of wind exergy efficiency. A solar efficiency map for Europe is also developed and is a guide for choosing a renewable energy based on yearly energy production.

Keywords: Renewable Energy, Solar, Wind, Exergy, Energy, Efficiency, Map.

\section{Introduction}

Nowadays, European Union is considering renewable resources as major components of future energy mix and has set more and more stringent objectives (see EC2009). Renewable resources can be segmented by their converters: sun power (thermal or electric), wind power, tide power, geothermic, hydraulic and bio-fuels. Clean energy cluster must be chosen carefully and in relation with local context and constraints. Lovejoy (1996) described the necessity of solar energy as regards population, finite resources (fossil or nuclear fuels) and pollution. Use of renewable resources must challenge the intermittent production and a time gap between production and consumption, see Sovacool (2009). Hoicka and Rowlands (2011) have proposed to view solar and wind as complementary resources. Exergy analysis is a smart tool for comparison between these different applications from a thermodynamic point of view, providing a more relevant insight about the energy losses than an energy analysis (Dincer 2002). Koroneos et al. (2003) have compared numerous types and uses of energy solutions (Solar/Thermal, Wind/Electric, Geothermal, Solar/Electric and other non renewable associations) using exergy analysis. They have essentially introduced the following:

- The energy consumed in order to construct the plant, also called energy invested. 
- The energy produced, also called output energy.

- The net energy produced is the difference between output energy minus energy invested.

- The input energy is the primary energy, for example the energy received by the collectors in case of solar thermal power systems, or the geothermal fluid energy in case of geothermal power plants, and so on.

They also concluded the association Solar/Thermal has the best ratios compared to other solutions: Net Energy Produced to Energy Invested and Output Energy to Input Energy.

Renewable resources (solar, wind and bio-fuels) can be seen as rival solutions requiring ground, except off-shore installation. Table 1 summarizes their respective advantages and drawbacks, see Kreith and Goswami (2007). Nevertheless, bio-fuels are still a controversial solution since there is a risk of using the food resources to produce the biofuels (Gasparatos et al. 2011). Consequently, we chose not to include this solution in this paper.

Renewable sources can be considered in off-grid applications, often associated with a diesel engine see Akyuz et al. (2009, 2011, 2012a), or connected to a national grid, considered as an electric "well", as in this paper.

The main aim of this paper is to define the exergy efficiency of solar and wind converters over Europe as regards yearly production with an iso-area of land-use Based on the literature review presented in section 2, the paper proposes two converter models, one for each renewable resource (Joshi et al. 2009, and Pedersen et al. 1992). Meanwhile, a study of sensibility is performed with relevant weather inputs (temperature, pressure, $\mathrm{RH}$, global radiation, wind speed). Yearly energy and exergy production maps are then established over Europe and discussed in section 4. Such maps can be a useful tool for cost analysis. Weather DOE database (Department of Energy, USA) available online is the source to build a "typical" year for 8,760 representative hours over 20 years.

Furthermore, the paper focuses on the physics (thermodynamics) underlying the energy options, in order to assess and compare their theoretical potentials according to exergy and energy indicators. The aim is to provide an objective basis upstream to the decision-making process, where the constraints specific to given projects would be taken into account additionally in further stages (e.g., land use, visual impact, noise, infrastructure requirements, etc.). Moreover, while the European Union has set targets for renewable energy production at the European level, each Member State may implement its own policies to meet its goals. Therefore, the economic and regulatory conditions (regulations, incentives, etc.) vary from one country to the other. These aspects are thus not included in our analyses either. This is indeed the topic for another field of literature (see e.g., Johansson and Turkenburg 2004, Jäger-Waldau 2007). 
Nevertheless, over Europe, it can exist areas where the competition between solar and wind energy can be effective in terms of yearly electric production; next the previous considerations can take place. For example in France, the common idea is: wind turbines are

130 always a better solution in term of electric production and when constraints appear, you can resort to PV cells.

Table 1: Advantages/Drawbacks of wind turbines and PV cells

\section{METHODOLOGICAL BACKGROUND}

Several authors have developed exergy model to analyse renewable energy systems. For example, Sahin et al. (2006a and 2006b) have defined an exergy model of wind turbine

Pope et al. (2010) have extended this approach by taking into account the type of wind

140 turbines (horizontal or vertical axis). In parallel, Joshi et al. (2009) have proposed a model for

141 a photovoltaic thermal system. They have also explained their methodology in terms of exergy analysis and weather dependences. This section reviews the theoretical background of these models and perform sensitivity analyses for the weather parameters in order to classify them according to their order of influence on the exergy efficiency.

\subsection{Solar energy option}

147 The exergy of global solar radiation can be performed as Jeter (1981) proposes:

$148 \dot{E} x^{s}=\left(1-\frac{T_{\text {amb }}}{T_{\text {sun }}}\right) \phi_{S} A_{\text {cell }}$

149 This exergy amount is spread out into an electric power and a thermal power. Electrical 150 power is deduced as proposed by Joshi et al. (2009):

$151 \dot{E} x_{e}^{s}=\eta_{\text {cell }} \dot{E} x^{s}$

152 The electric efficiency $\eta_{\text {cell }}$.depends on the technology (crystalline or thin film, cell or 153 module), see web site of University of Michigan. We use $12 \%$ as a default value, and we 154 define its theoretical limit when comparing PV cell and HAWT, see section 4.3.

155 There are two possibilities for the estimation of thermal power $\dot{Q}_{\text {cell }}$, either by 156 considering heat transfer as a function of wind speed, see Akyuz et al. (2012b) or by 157 enthalpy balance based on mass flow rate of the flowing air (cooling system), see Joshi et al. 158 (2009). For ensuring the model homogeneity, the thermal power $\dot{Q}_{\text {cell }}$ is calculated with 159 Joshi's approach:

$160 \dot{Q}^{\text {cell }} \approx \dot{m}_{a} C p_{a}\left(T_{\text {cell }}-T_{\text {amb }}\right)$

161 where $T_{\text {cell }}$ is estimated from Skoplaki et al. (2008) relation: 
163 Here $k$ is the Ross coefficient and its value ranges from 0.021 (for free standing PV array

164 mounting) to 0.054 (for opaque PV surface), see Skoplaki et al. (2008). Joshi et al. (2009)

165 have used a $k$-value of 0.054 as the PV/T surface considered in their study was opaque.

166 Since the correlation is simple and links $T_{\text {cell }}$ with the ambient temperature and the incident

167 solar radiation flux, it is appropriate for the prediction of the cell temperature, in a range of

168 ambient temperature of $\left[20-35^{\circ} \mathrm{C}\right]$, that means a range of cell temperature of $\left[50-80^{\circ} \mathrm{C}\right]$.

169 Consequently, the thermal exergy rate of $\mathrm{PV}$ cell is defined as

$\dot{E} x_{t h}^{s}=\left(1-\frac{T_{a m b}}{T_{\text {cell }}}\right) \dot{Q}^{\text {cell }}$

171 The thermal exergy efficiency $\psi_{t h}^{s}$ is given by $\psi_{t h}^{e}=\frac{\dot{E} x_{t h}^{s}}{\dot{E} x^{s}}$. Then, PV cell exergy efficiency can

172 be defined as

$$
\psi^{s}=\frac{\dot{E} x_{e}^{s}+\dot{E} x_{\text {th }}^{s}}{\dot{E} x^{s}}=\eta_{\text {cell }}+\frac{\left(1-\frac{T_{\text {amb }}}{T_{\text {cell }}}\right) \dot{Q}_{\text {cell }}}{\left(1-\frac{T_{\text {amb }}}{T_{\text {sun }}}\right) \phi_{S} A_{\text {cell }}}
$$

174 Exergy efficiency of PV cell is decomposed by its electrical and thermal parts (using Joshi's model). Hence these exergies are plotted versus ambient temperature, see figure 1, and versus global solar radiation, see figure 2 .

The higher the ambient temperature, the lesser the thermal exergy efficiency is, and consequently the lesser the total exergy efficiency is (by assuming that global solar radiation is constant), but this effect can be classified as a second order. For example, ambient temperature in the range of $\left[0-30^{\circ} \mathrm{C}\right]$ involves a variation on total exergy efficiency in the "reverse" range of [32\%-30\%].

182 The higher the global solar radiation, the higher the thermal exergy efficiency is, and consequently the higher the total exergy efficiency is (by assuming that ambient temperature is constant). This effect is classified as a first order. For example, direct radiation in the range of 50-650 Wh m $\mathrm{W}^{-2}$ involves a variation on total exergy efficiency in the range of [13\%-37\%].

\subsection{Wind energy}

193 Wind kinetic energy is converted to electrical power by moving a wind turbine. Consequently,

194 the instantaneous pressure drop $\Delta P$, between upstream and downstream of the wind 
195 turbine, can be modelled as two thermodynamic states, denoted by the subscript 1 for 196 upstream and 2 for downstream.

$197 \Delta P(t)=P_{1}(t)-P_{2}(t)$

198 Let's assume that firstly the linear turbine speed, noted $V$, is the average between up- and 199 down-stream:

$200 \quad V=\frac{V_{1}+V_{2}}{2}$

201 and secondly $\frac{V_{2}}{V_{1}}$ is small.

202 Then, by using the Barré de St Venant equation, one can write by neglecting enthalpy 203 variations:

$204 \quad \frac{P_{1}}{\rho}+\frac{V_{1}^{2}}{2}=\frac{P_{2}}{\rho}+\frac{V_{2}^{2}}{2} \Rightarrow V^{2}=\frac{2}{\rho} \Delta P$

205 Sahin et al. (2006a) have described a wind turbine model by adapting the wind chill 206 temperature to this application:

$$
T_{\text {windchill }, i}=35.74+0.6215 T_{a}-35.75 V_{i}^{0.16}+0.4274 T_{a} V_{i}^{0.16}
$$

208 where $i \in\{1,2\}$.

209 Thermodynamic states and specific "thermodynamic" exergy function of wet air are detailed 210 by Dincer and Rosen (2007):

$$
e x^{\text {th }}=\left(C p_{a}+\omega C p_{V}\right) T_{0}\left[\left(T / T_{0}\right)-1-\ln \left(T / T_{0}\right)\right]+\left(R_{a}+R_{V} \omega\right) T_{0} \ln \left(P / P_{0}\right)+
$$

$$
T_{0}\left[\left(R_{a}+R_{V} \omega\right) \ln \left(\frac{R_{a}+R_{V} \omega_{0}}{R_{a}+R_{V} \omega}\right)+R_{v} \ln \left(\frac{\omega}{\omega_{0}}\right)\right]
$$

212 with $R_{a}$ the air gas constant $\left(R_{a}=287 \mathrm{~J} / \mathrm{kg} \mathrm{K}\right), \quad R_{v}$ the water gas constant $213\left(R_{v}=461.5 \mathrm{~J} / \mathrm{kg} \mathrm{K}\right), C p_{a}$ the specific heat of air $(1002 \mathrm{~J} / \mathrm{kg} \mathrm{K})$ and $C p_{v}$ the specific heat of 214 vapour at reference temperature $\left(1869 \mathrm{~J} . \mathrm{kg} / \mathrm{K}\right.$ at $\left.25^{\circ} \mathrm{C}\right)$. Subscript 0 refers to dead state 215 corresponding to ambient conditions; see Gaggioli (2012) or Sogut et al. (2009).

216 Then, exergy function is

$217 E x^{\text {th }}=\dot{m} e x^{\text {th }}$

218 where the specific humidity ratio:

$219 \omega=\frac{\dot{m}_{w}}{\dot{m}}$

220 where $\dot{m}$ is obtained with the continuity equation:

$221 \dot{m}=\rho A_{W} V$

222 Golding (1955) has established the maximum power $\hat{\dot{W}}$ that can be extracted for given 223 weather conditions: 
$224 \quad \hat{\dot{W}}=\frac{8}{27} \rho A V_{1}^{3}$

225 Horizontal-axis wind turbines (HAWT), a more realistic model for power $\dot{W}$, is provided by

226 Pedersen et al. (1992), see figure 3. This model of electric power versus wind speed is 227 proposed for an optimal pitch angle and angle of attacks, see Thumthae and Chitsomboon 228 (2009) for their definitions. To omit the wind direction, the authors assume that HAWT is 229 equipped with yaw bearing system and untwisted blade. HAWT features are: rotor diameter $23018 \mathrm{~m}$, hub length $30 \mathrm{~m}$, nominal power $100 \mathrm{~kW}$.

\section{Figure 3: Electric power versus wind speed for HATW (Pedersen's model)}

235 maximum power and is plotted in figure 4:

$236 \quad \eta=\frac{\dot{W}}{\hat{\dot{W}}}$

237 It is very important to highlight that such a wind turbine has its maximum electric efficiency

238 for a wind speed of around $8 \mathrm{~m} / \mathrm{s}$. Beyond this limit the power increases with wind speed but 239 the efficiency decreases.

240 Then, wind exergy efficiency can be defined as:

$$
\psi^{W}=\frac{\dot{W}}{\Delta\left(\frac{1}{2} \dot{m} V^{2}+E x^{w}\right)}=\frac{\dot{W}}{\frac{1}{2} \dot{m}\left(V_{1}^{2}-V_{2}^{2}\right)+E x_{1}^{w}-E x_{2}^{w}}
$$

242 Note that Hellmann equation gives the wind speed correction taking into account wind 243 turbine hub:

$$
244 \quad V_{\text {corr }}=V_{\text {meas }}\left(\frac{H}{H_{\text {meas }}}\right)^{\alpha} \text { with } \alpha=0.28
$$

245 For this model, instantaneous ambient conditions are defined by: temperature, wind speed, 246 pressure and relative humidity. Then, the weather database of DOE is required to perform 247 the sensitivity analyses.

248 Energy efficiency of HATW (using Pedersen's model), see Eq (15), is plotted in 249 Figure 4. Maximum energy efficiency, 50\%, corresponds with $8 \mathrm{~m} / \mathrm{s}$. The transfer function 250 between wind speed and electric efficiency is non linear and its shape is like a "dome": a 251 same value of energy efficiency can correspond with a low or a high wind speed, and thus a 252 low or high electrical power. Therefore, an analysis of HATW energy efficiency cannot be 253 done in a straightforward manner. It requires to set first either the wind speed or the electric 254 power. 
Figure 4: Electric efficiency for HATW (Pedersen's model)

Typical values of pressure variations between upstream and downstream ( $\Delta P$ as defined by eq(1)) and temperature variations are given in Table 2.

Table 2 : Pressure and temperature variations

Exergy efficiency of HATW (using Pedersen's model), see Eq (16), is plotted in Figure 5a). The shape between exergy efficiency of HATW (Pedersen's model) and wind speed is approximately the same as previously, with its maximum exergy efficiency, around $35 \%$, for a wind speed of $7 \mathrm{~m} / \mathrm{s}$, in the specified conditions. It is worth to propose a parametric study of exergy efficiency as regards these conditions:

- Ambient temperature effect on exergy efficiency is plotted in Figure 5-b). This effect is very significant and must be associated to the wind chill temperature. This effect can be classified as a first order.

- Ambient pressure and relative humidity effects on exergy efficiency are plotted in Figure 5-c) and Figure 5-d) respectively. These effects are not significant and are classified as a second order. The slops are $2010^{-6}$ for ambient pressure and -4.6 10-8 for relative humidity.

Figure 5: Exergy efficiency for HATW (Pedersen's model): a) wind speed effect,

b) ambient temperature effect,

c) ambient pressure effect, and

d) relative humidity effect.

\section{CASE STUDY FOR EUROPEAN UNION}

Using Joshi's model for PV cells and Pedersen's model for HATW, we computed the exergy efficiency for average weather conditions of a set of locations across Europe. As an example, data and results (exergy efficiencies for PV cells and wind power) for Paris (France) are detailed in this section.

The models require weather data:

- wind speed

- ambient temperature

- ambient pressure

- global radiation

- relative humidity

These data are available on DOE website for various meteorological stations and for a "representative" year with its 8760 hours. This choice requires more CPU-time than monthly 
data, but it avoids introducing additional uncertainties due to the estimation of data distribution, see Coskun et al. (2011).

An assumption was also needed to take into account the difference in the land use for both systems (solar PV and wind power). A usual building layout of wind turbines is a separation of at least around 5 times the rotor length to avoid fluid mechanic interactions. Then, in this study, the authors have considered that the PV cell area is 5 times the cross area of the wind turbines, that is to say $1,200 \mathrm{~m}^{2}$. Cumulative energy or exergy have been calculated for this surface.

The exergy efficiency defined from Joshi's model for PV cells is a function of ambient temperature and direct radiation, see figure 6 . As explained before, ambient temperature has a second order effect, then the main relation between this exergy efficiency and global radiation is mostly independent of ambient temperature.

Figure 6: Total exergy efficiency of PV cell versus direct radiation for Paris

The wind speed over 8760 hours is plotted in Figure 7-a): the wind speed range is [020] $\mathrm{m} / \mathrm{s}$. Statistical tools are commonly used to analyse such data: the cumulative normal distribution of hourly wind speed in interval $\left[v_{j} ; v_{j+1}\right]$ is the number of times that the hourly wind speed (based on DOE database) occurs in this interval over the year. Same procedure is applied to wind power. Figure 7-b) gives information about cumulative normal distributions of hourly wind speed (see Kantar and Usta (2008), Ulgen and Hepbasli (2002)) and its associated wind power. These distributions show clearly the gap between hourly distribution and power distribution, hence $25 \%$ of the energy is produced only during $3 \%$ of the year where the wind speed is $11 \mathrm{~m} / \mathrm{s}$. Such a gap was well expected, see Chang (2010). Monthly wind direction is showed for three months (January, May and June) and reveals very large orientation discrepancies, see Figure 7-c). distribution. The monthly average temperatures are plotted in figure 8-a), and its range is [3-

Figure 7: a) Representative year of wind speed for Paris

b) Cumulative normal distribution of wind speed and its associated wind power for Paris c) Monthly wind direction for three months (January, May and June) for Paris

Figure 8: a) Monthly ambient temperature at Paris

b) Monthly direct radiation at Paris 
The exergy efficiency for HAWT (using Pedersen's model) is a function of ambient conditions as well. But there are crossed effects not so obvious. In Figure 9, the wind exergy efficiency is plotted (for Paris):

- versus wind speed: as expected, the faster the wind speed, the greater the wind exergy, but this observation is within an envelope: this shape shows a first order effect, see Figure 9-a).

- versus ambient temperature: an upper linear limit seems to exist. There is a significant scattering then these coupled effects are important, see Figure 9-b).

- versus ambient pressure: this parameter has a second order effect, then no tendency can be proposed, see Figure 9-c).

More than 100 meteorological stations have been considered, see figure 10, to represent

Figure 9: Hourly exergy efficiency of HAWT

$$
\text { a) versus wind speed }
$$

b) versus ambient temperature

c) versus ambient pressure

d) versus relative humidity

Europe. Spline interpolation is performed with common Sandwell algorithm (1987).

\section{Results and Discussion}

\subsection{Primary exergy}

By "primary exergy", authors mean the exergy amount: this amount is calculated by eq (4) for solar resources, and by eq (11) for wind resources. A cumulative amount is then computed over the year, see Figures 11.

- The European Commission's Joint Research Centre in Ispra published an interactive map of Europe (and Africa) showing the photovoltaic solar electricity potential, see EC website. Figure 11 -a) shows the latitude $45^{\circ}$ as a good limit. Two singular locations must be underlined: one near London (UK) and a second one near Göteborg (Sweden).

- An European Wind Atlas has been published for the European Commission by the Risø National Laboratory, see EWA website. Wind "primary exergy" is very significant on the west coast and especially in Ireland, see figure 11-b). On Mediterranean coast, an important wind, called "mistral", blows near Marseille (France). EWA wind zones have been plotted in dotted lines in Fig 11-b). These zones have a good concordance with these obtained by our computations. 
Figure 11: Primary exergy from a) sun and b) wind resources

\subsection{Real conversion}

Cumulative electric power is performed from eq (2) for sun resource and by using eq (15) for wind resource (with weather inputs from DOE database).

- For sun resource, real cumulative electric power is plotted in Figure 12-a). With an electric efficiency of $12 \%$, the maximum cumulative electric power is only $240 \mathrm{MWh} / \mathrm{y}$, under the latitude $45^{\circ}$.

- For wind resource, real cumulative electric power is plotted in Figure 12-b). In this configuration, the maximum cumulative electric power is around $600 \mathrm{MWh} / \mathrm{y}$. Its electric conversion benefits from the number of hours of availability for the considered resource.

Figure 12: Yearly electric production a) solar resource b) wind resource

Electric energy predicted from wind resource versus sun resource for each meteorological station is plotted in Figure 13. On this plot, the first bisectrix line has been added and y-axis has been reshaped. Below this bisectrix line, one can determine few stations (in Austria: Insbruck and Linz, in Italia: Messina, Valence and Venice, in Slovakia: Brastilava, in Spain: Valencia, and in Roumania: Cluj and Constanta) where sun resource could be interesting in term of electric energy.

Figure 13: Wind energy potential versus sun energy potential for the 100 meteorological stations tested

Exergy efficiencies are then detailed as follows:

- Solar exergy efficiency, averaged over the year, is calculated from eq (5) and plotted in figure 14-a). Since electrical efficiency is taken as $12 \%$, this plot shows that "thermal exergy efficiency" is in the range [5-15]\%. A point worth mentioning here is that the combined heat and power production from a PV/T system would increase the usability of the system. Also a good electrical efficiency can be maintained throughout the day as the thermal exergy from the system would have affected the latter adversely otherwise removed from the $\mathrm{PV}$ panels.

- Wind exergy efficiency, averaged over the year, is calculated from eq (16) and plotted in Figure 14-b). This plot must be very carefully read because HAWT exergy efficiency against wind speed is roughly a parabolic shape (see figure 5-a)). Indeed, the maximum exergy efficiency is obtained for a wind speed around $7 \mathrm{~m} / \mathrm{s}$. while the maximum electric production is achieved for $13.5 \mathrm{~m} / \mathrm{s}$. In other words, West Ireland coast can produce the 
greater amount of electricity but its exergy efficiency is lower than other places (where the wind speed is closer to $7 \mathrm{~m} / \mathrm{s}$ ). This point underlines that wind turbines must be designed for the place where they are located. Since no heat is recoverable by this converter, wind exergy efficiency is lower than the sun one. But in practice, most of the PV systems do not recover the "waste" heat either.

Figure 14: Yearly exergy efficiency a) solar resource b) wind resource

\subsection{Solar/Wind electric production challenge}

As shown in the previous results, solar resource is more penalized by its intermittent feature than wind resource. It is then interesting to ask: What would be the required solar electric efficiency to exceed HAWT electric production? Knowing HATW electric production and available direct radiation both cumulated over year, the ratio of both would give this solar electric efficiency theoretical threshold. Solar efficiency theoretical thresholds are plotted in figure 15 for the locations tested.

- Near North Sea coasts (France, Belgium, Germany, The Netherlands), Baltic sea coasts and UK, the solar efficiency theoretical threshold would be over $40 \% .40 \%$ is beyond the current technological limits for solar efficiency, which is about $30 \%$ see MU web site. Consequently, solar production can not challenge wind production in these regions.

- Near Mediterranean Sea coast in France, wind resource called "mistral" is in competition with solar resource since real electric efficiency is nowadays technologically feasible since the solar electric efficiency theoretical threshold can be met with current technology.

- Above the latitude $45^{\circ}$, solar resource can already produce more electricity than wind resource.

This paper just provides a tendency, not an exact result: an assessment for a specific application is still required to go further in the decision process.

Figure 15: Solar electric efficiency theoretical threshold

\section{CONCLUSIONS}

Solar and wind resources have extensively been studied over Europe in terms of: available resources, real conversion, and exergy efficiency. To achieve these maps, a complete study of influencing parameters is firstly performed using two classical models (Joshi's model for PV cells and Pedersen's model for HATW). Global radiation is the main parameter for PV cells' model and wind speed for HATW model. Ambient temperature is a major parameter for exergy calculations for both. Hourly weather DOE database are used for Europe and compared qualitatively to the literature data and maps. Then, we obtain with the DOE 
database the maps of renewable resources over Europe. For solar resource, the latitude $45^{\circ}$ is clearly a limit to produce a significant amount of electricity. For wind resource, 4 regions (North sea coasts, Baltic sea coasts, a specific coast of Mediterranean sea and UK) are very effective for electrical production.

To challenge wind resource by solar resource, authors have evaluated a theoretical $\mathrm{PV}$ electrical efficiency threshold. If one accepts a maximum value of electric conversion efficiency around $40 \%$, the previous four regions are not effective for solar energy (whatever the technological progress). This result, more or less intuitive, is consequently established on a thermodynamic point of view with the DOE weather database without any cost consideration. Renewable energy is sometimes more ideological than scientific. Then this kind of study could be complete by economic and regulatory conditions (regulations, incentives, etc.) to be useful for decision makers.

\section{References}

Akyuz, E., Oktay, Z. and Dincer, I. (2009) The technico-economic and environmental aspects of a hybrid PV-Diesel-battery power system for remote farm houses, Int. J. Global Warning, Vol. 1, pp392-404.

Akyuz, E., Oktay, Z. and Dincer, I. (2011) Energetic, environmental and economic aspects of a hybrid renewable energy system: a case study, Int. J. of Low-Carbon Technology, Vol. 6, pp 44-54.

Akyuz, E., Oktay, Z. and Dincer, I. (2012a) A case study of hybrid wind-solar power system for reduction of CO2 emissions, Int. J. Global Warning, Vol. 4, pp52-67.

Akyuz, E., Coskun, C., Oktay, Z. and Dincer, I. (2012b) A novel approach for estimation of photovoltaic exergy efficiency, Energy, Vol. 44, pp 1059-1066.

Chang, T.P. (2010) Wind speed and power density analyses based on mixture Weibull and maximum entropy distribution, Int. J. Applied Science and engineering, Vol. 8, pp. 39-46.

Coskun, C., Oktay, Z. and Dincer, I. (2011) Estimation of monthly solar radiation distribution for solar energy system analysis, Energy, Vol. 36, pp1319-1323.

Dincer I. (2002) The role of exergy in energy policy making, Energy Policy, Vol. 30, pp. 137149.

Dincer, I. and Rosen, M.A. (2007) Exergy: energy, environment and sustainable development, Ed. Elsevier, ISBN: 978-0-08-044529-8.

EC2009, Directive 2009/28/EC of 23 April 2009 on the promotion of the use of energy from renewable sources

Gaggioli, R. A. (2012) The dead state, Proceedings of ECOS 2012, Perugia, Italy, pp1-13.

Gasparatos, A., Stromberg, P, Takeuchi, K. (2011) Biofuels, ecosystem services and human wellbeing: Putting biofuels in the ecosystem services narrative, Agriculture, Ecosystems \& Environment, Vol. 142(3-4), pp. 111-128

Golding, E.W. (1955) The generation of Electricity by Wind Power, E\&F N. Spon Limited: London.

Hoicka, C.E. and Rowlands, I. H. (2011) 'Solar and wind resource complementarity: Advancing options for renewable electricity integration in Ontario, Canada', Renewable Energy, Vol. 36, pp. 97-107. 
Jäger-Waldau, A. (2007) Photovoltaics and renewable energies in Europe, Renewable and Sustainable Energy Reviews, Vol.11(7), pp. 1414-1437

Jeter, S.J. (1981) 'Maximum conversion efficiency for the utilization of direct solar radiation', Solar Energy, Vol.26, pp. 231-236.

Johansson T.B, Turkenburg, W. (2004) Policies for renewable energy in the European Union and its member states: an overview, Energy for Sustainable Development, Vol.8(1), pp. 5-24

Joshi, A. S., Dincer, I. and Reddy, B. V. (2009) 'Development of solar exergy maps', Int. J. Energy Res., Vol. 33 pp. 709-718.

Koroneos, C., Spachos, T. and Moussiopoulos, N. (2003) 'Exergy analysis of renewable energy sources', Renewable Energy, Vol. 28, pp. 295-310.

Kreith, F. and Yogi Goswami, D. (2007) Handbook of energy efficiency and renewable energy, CRC Press, ISBN 0-8493-1730-4.

Lovejoy, D. (1996) 'The necessity of solar energy', Renewable energy, Vol. 9, pp. 11381143.

Pedersen, T.F., Petersen, S.M., Paulsen, U.S., Fabian, O., Pedersen, B.M., Velk, P., Brink, M., Gjerding, J., Frandsen, S., Olesen, J., Budtz, L., Nielsen, M.A., Stiesdal, H., Petersen, K.Ø., Danwin, P.L., Danwin, L.J. and Friis, P. (1992). Recommendation for wind turbine power curve measurements to be used for type approval of wind turbines in relation to technical requirements for type approval and certification of wind turbines, in Denmark. Danish Energy Agency, September.

Pope, K., Dincer, I. and Naterer G.F. (2010), 'Energy and exergy efficiency comparison of horizontal and vertical axis wind turbines', Renewable energy, Vol. 35, pp. 2102-2113.

Sahin, A. D., Dincer, I. and Rosen, M. A. (2006a) Development of new spatio-temporal wind exergy maps, Proceedings of ASME 2006, Mechanical Engineering Congress and Exposition, Nov. 5-10, Chicago, Illinois, USA.

Sahin, A. D., Dincer, I. and Rosen, M. A. (2006b) 'Thermodynamic analysis of wind energy', Int. J. Energy Res., Vol. 30 pp. 553-566.

Sandwell, D. T., (1987) 'Biharmonic Spline Interpolation of GEOS-3 and SEASAT Altimeter Data', Geophysical Research Letters, Vol. 2, pp. 139-142.

Skoplaki, E., Boudouvis, A.G. and Palyvos, J.A. (2008) 'A simple correlation for the operating temperature of photovoltaic modules of arbitrary mounting,' Solar Energy Materials and Solar Cells, Vol. 92, pp. 1393-1402.

Sogut, Z., Oktay, Z. and Hepbasli, A. (2009) Invetsigation of effect of varying dead-state temperatures on energy and exergy efficiencies of a Raw Mill process in a cement plant, Int. J. Exergy, Vol. 6, pp. 655-670

Sovacool, B.K. (2009) 'The intermittency of wind, solar, and renewable electricity generators: Technical barrier or rhetorical excuse?', Utilities Policy, Vol. 17, pp. 288-296.

Thumthae, C. and Chitsomboon, T. (2009) 'Optimal angle of attack for untwisted blade wind turbine', Renewable Energy, Vol. 34, pp. 1279-1284.

Ulgen, K. and Hepbasli, A. (2002) Determination of Weibull parameters for wind energy analysis of Izmir, Turkey, Int. J. Energy Research, Vol. 26, pp. 495-506.

$\underline{\text { Website }}$

DOE, http://apps1.eere.energy.gov/buildings/energyplus/, last access 08/09/2012 
EC, http://re.jrc.ec.europa.eu/pvgis/apps/radmonth.php?lang=en\&map=europe, last access 08/09/2012

EWA, http://www.windatlas.dk/europe/About.html last access 08/09/2012

UM, http://css.snre.umich.edu/css_doc/CSSS07-08.pdf, last access 08/29/2012

\section{Nomenclature}

$\underline{\text { Symbols }}$

$\begin{array}{lll}A & \text { rotor swept area } & {\left[\mathrm{m}^{2}\right]} \\ A_{\text {cell }} & \text { cell area } & {\left[\mathrm{m}^{2}\right]} \\ C p & \text { heat capacity at constant pressure } & {\left[\mathrm{J} \mathrm{kg}^{-1} \mathrm{~K}^{-1}\right]} \\ \dot{E} x & \text { exergy rate } & {[\mathrm{W}]} \\ P & \text { pressure } & {[\mathrm{Pa}]} \\ \dot{Q} & \text { thermal power } & {[\mathrm{W}]} \\ R & \text { specific gas constant } & {\left[\mathrm{J} \mathrm{kg}^{-1} \mathrm{~K}^{-1}\right]} \\ T & \text { temperature } & {[\mathrm{K}]} \\ V & \text { speed } & {\left[\mathrm{m} \mathrm{s}^{-1}\right]} \\ \dot{W} & \text { wind turbine power } & {[\mathrm{W}]^{-1}} \\ \mathrm{ex} & \text { specific exergy } & {\left[\mathrm{J} \mathrm{kg}^{-1}\right]} \\ \dot{m} & \text { mass flow rate } & {\left[\mathrm{kg} \mathrm{s}^{-1}\right]} \\ \mathrm{t} & \text { time } & {[\mathrm{s}]}\end{array}$

Greek letters

\begin{tabular}{|c|c|}
\hline$\Delta$ & difference \\
\hline$\Psi$ & exergy efficiency \\
\hline$\eta$ & energy efficiency \\
\hline$\phi$ & directsolar radiation \\
\hline$\rho$ & density \\
\hline$\omega$ & specific humidity ratio \\
\hline \multicolumn{2}{|l|}{ Subscripts } \\
\hline 0 & means reference conditions, i.e. ambient conditions \\
\hline 1 & upstream \\
\hline 2 & downstream \\
\hline V & referred to water vapor \\
\hline a & referred to air \\
\hline$e$ & electric \\
\hline$i$ & index \\
\hline$a m b$ & ambient conditions \\
\hline cell & solar PV cell \\
\hline corr & Hellmann's correction \\
\hline meas & mean measurement conditions \\
\hline sun & sun \\
\hline windchill & wind chill \\
\hline \multicolumn{2}{|l|}{ Exponents } \\
\hline th & thermodynamic \\
\hline$W$ & wind \\
\hline$S$ & solar \\
\hline \multicolumn{2}{|l|}{ Notation } \\
\hline 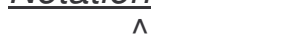 & maximum \\
\hline
\end{tabular}




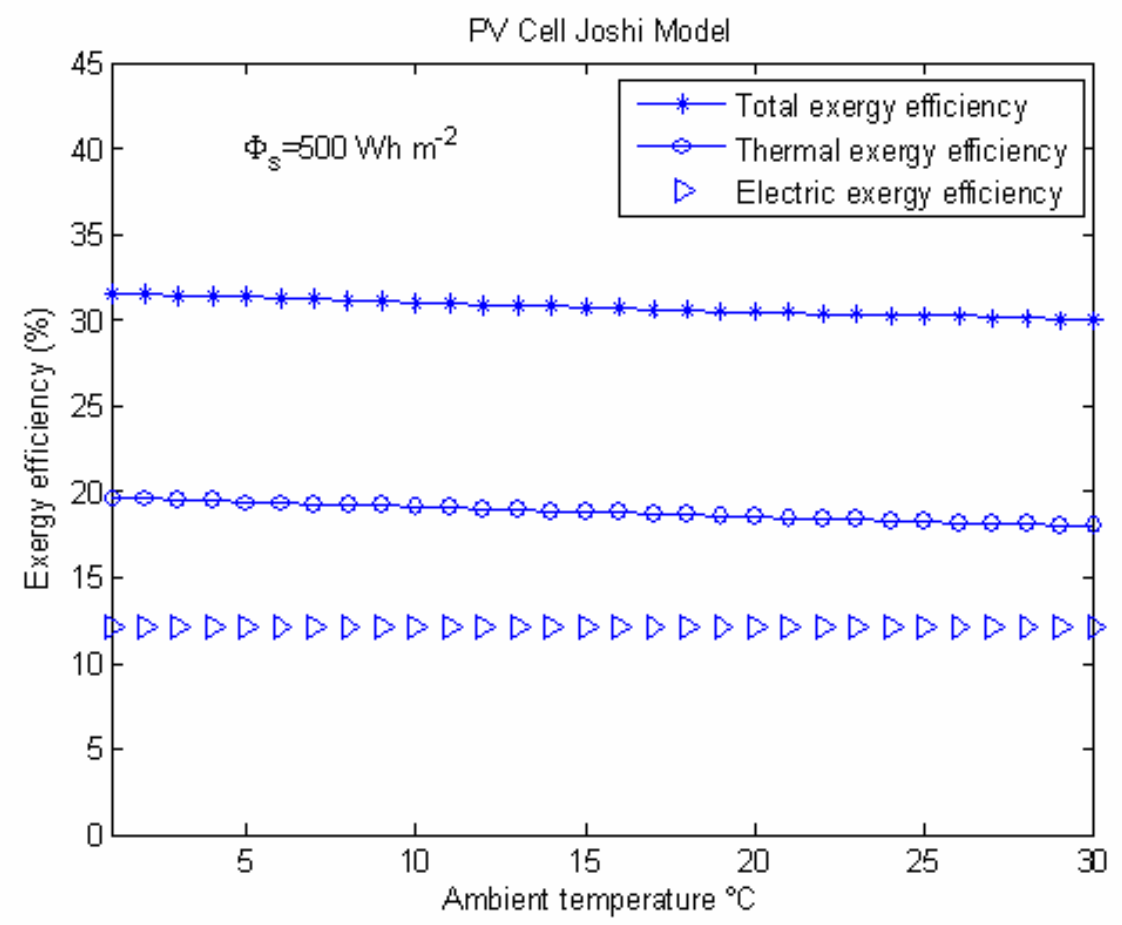

Figure 1: Exergy efficiency for PV cell (Joshi's model): ambient temperature effect 


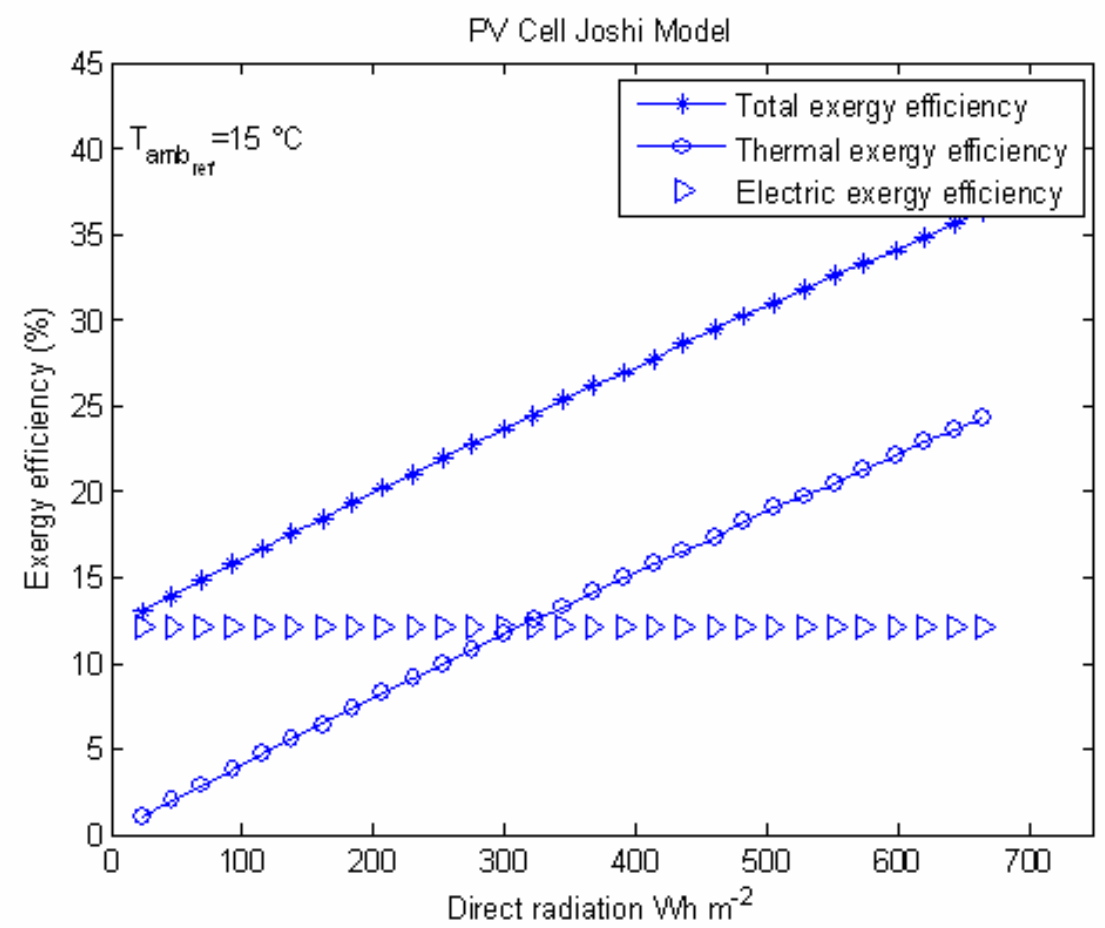

Figure 2: Exergy efficiency for PV cell (Joshi's model): global solar radiation effect 


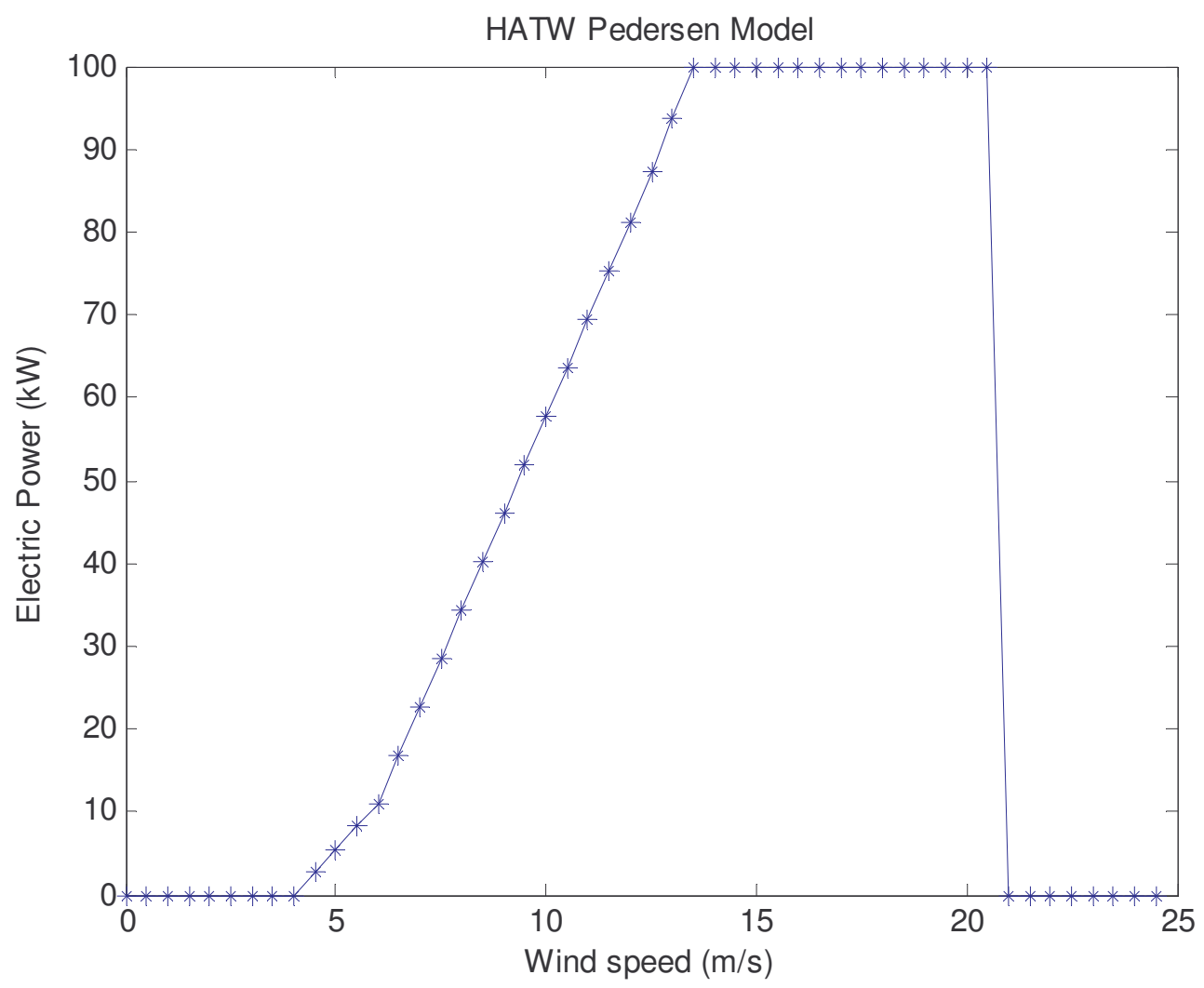

Figure 3: Electric power versus wind speed for HATW (Pedersen's model) 


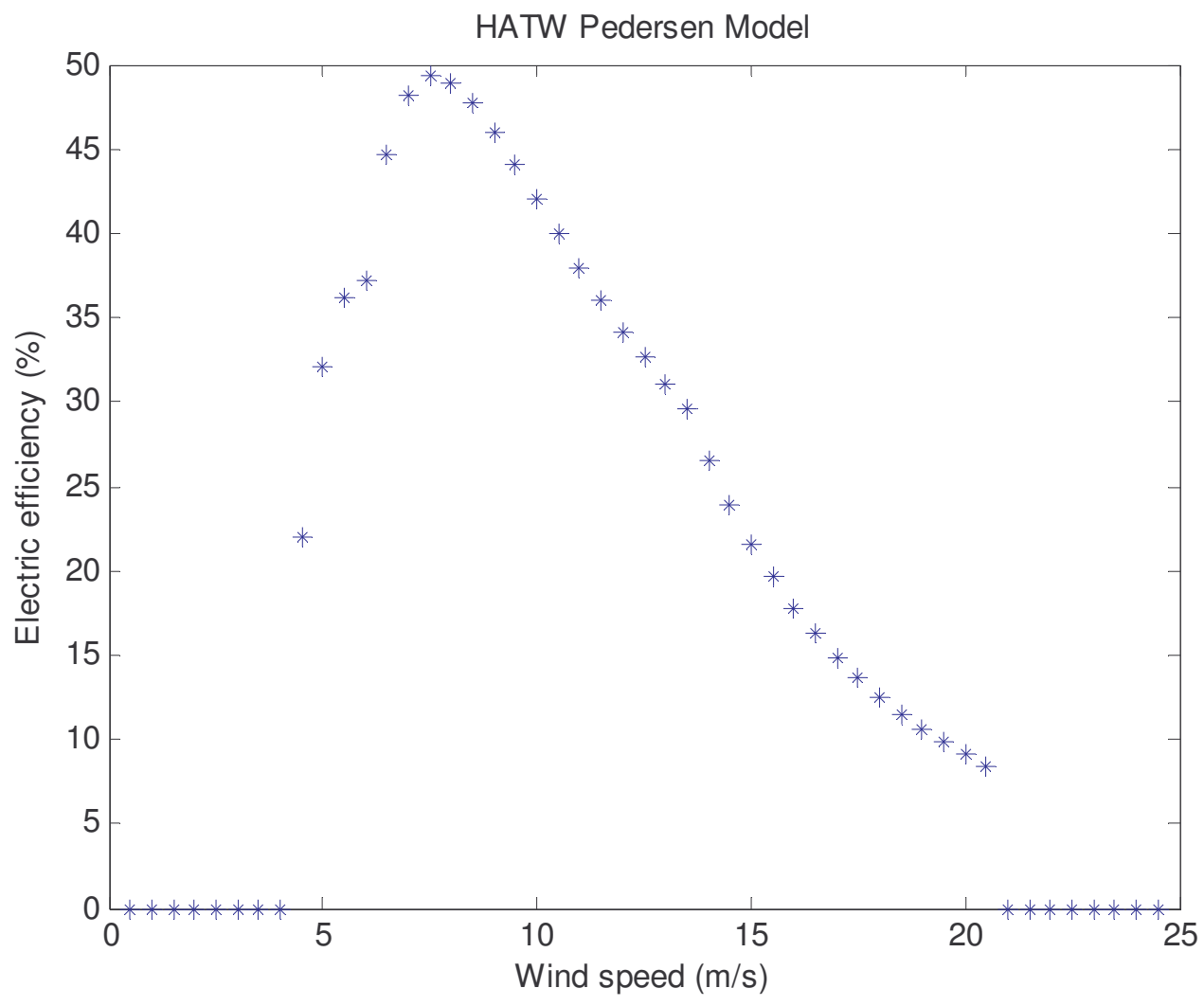

Figure 4: Electric efficiency for HATW (Pedersen's model) 
601

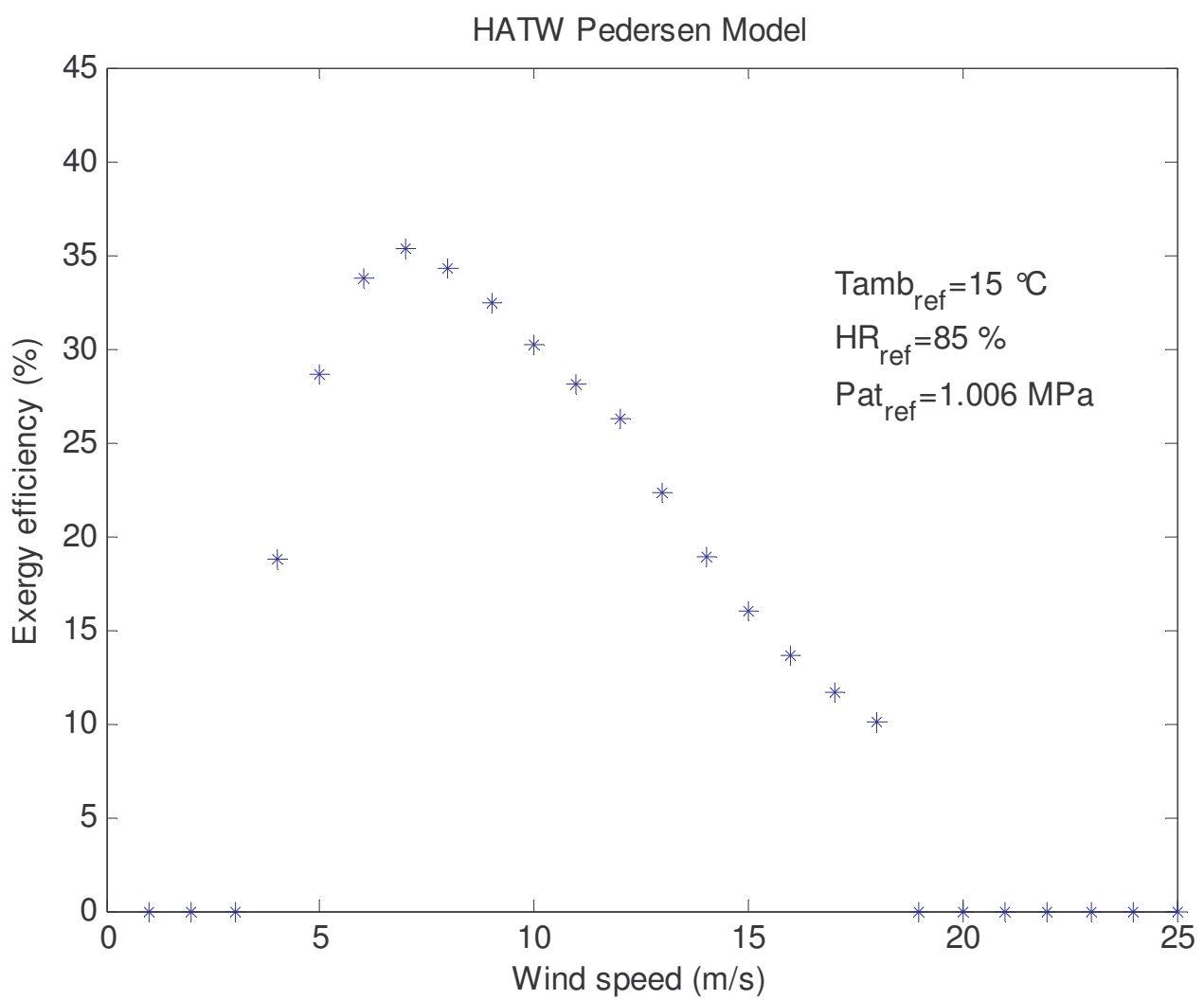

602

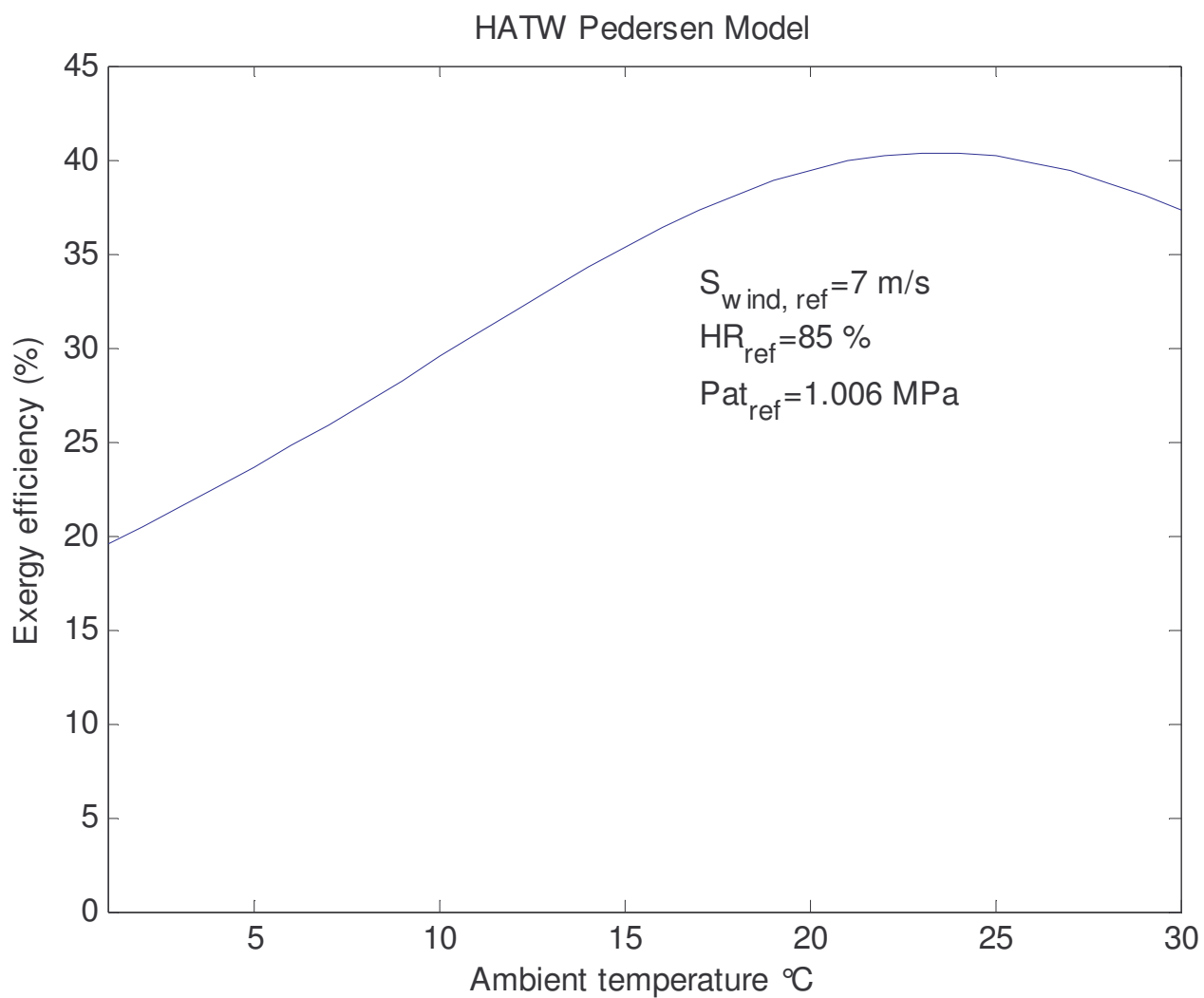

603 


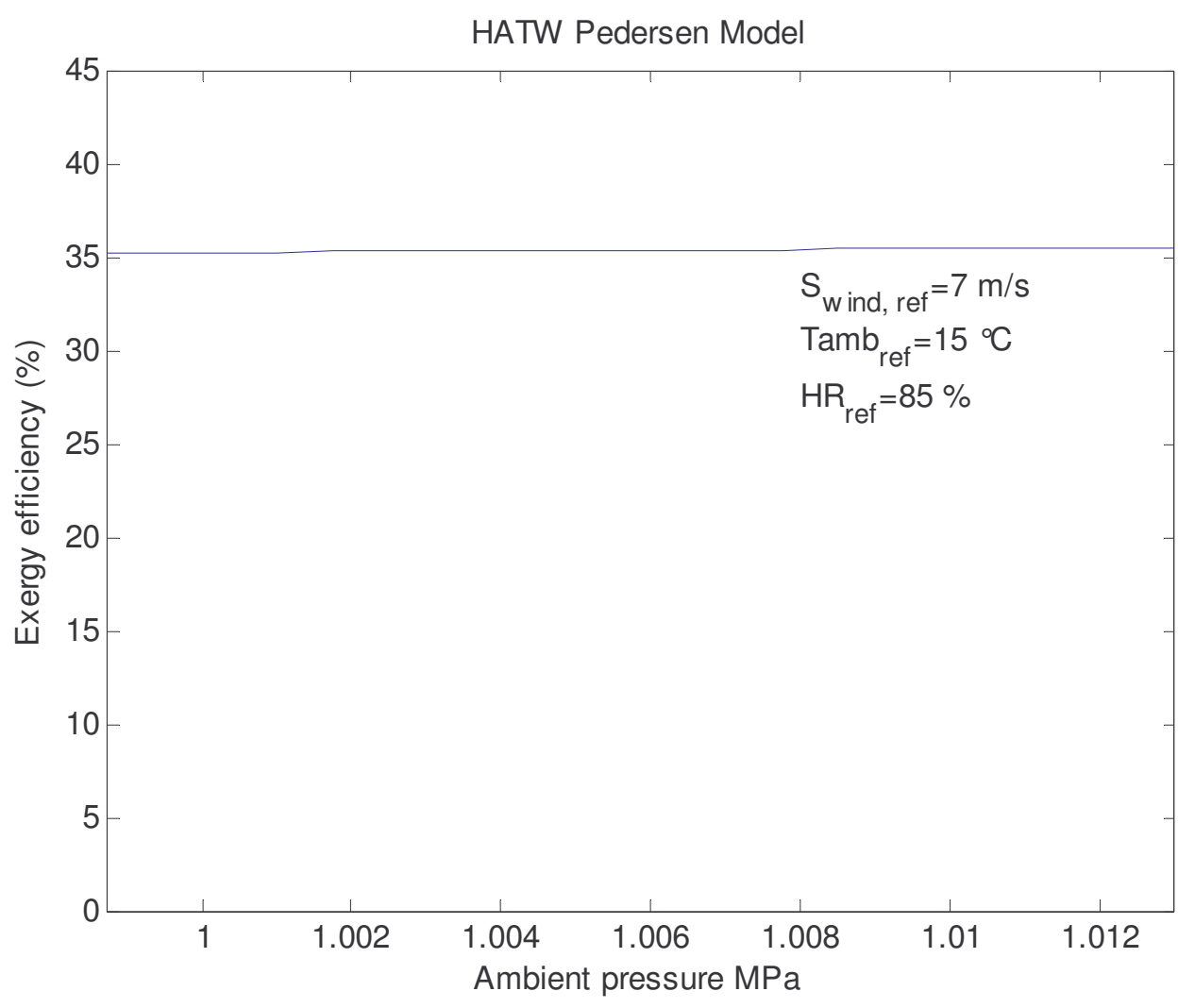

604

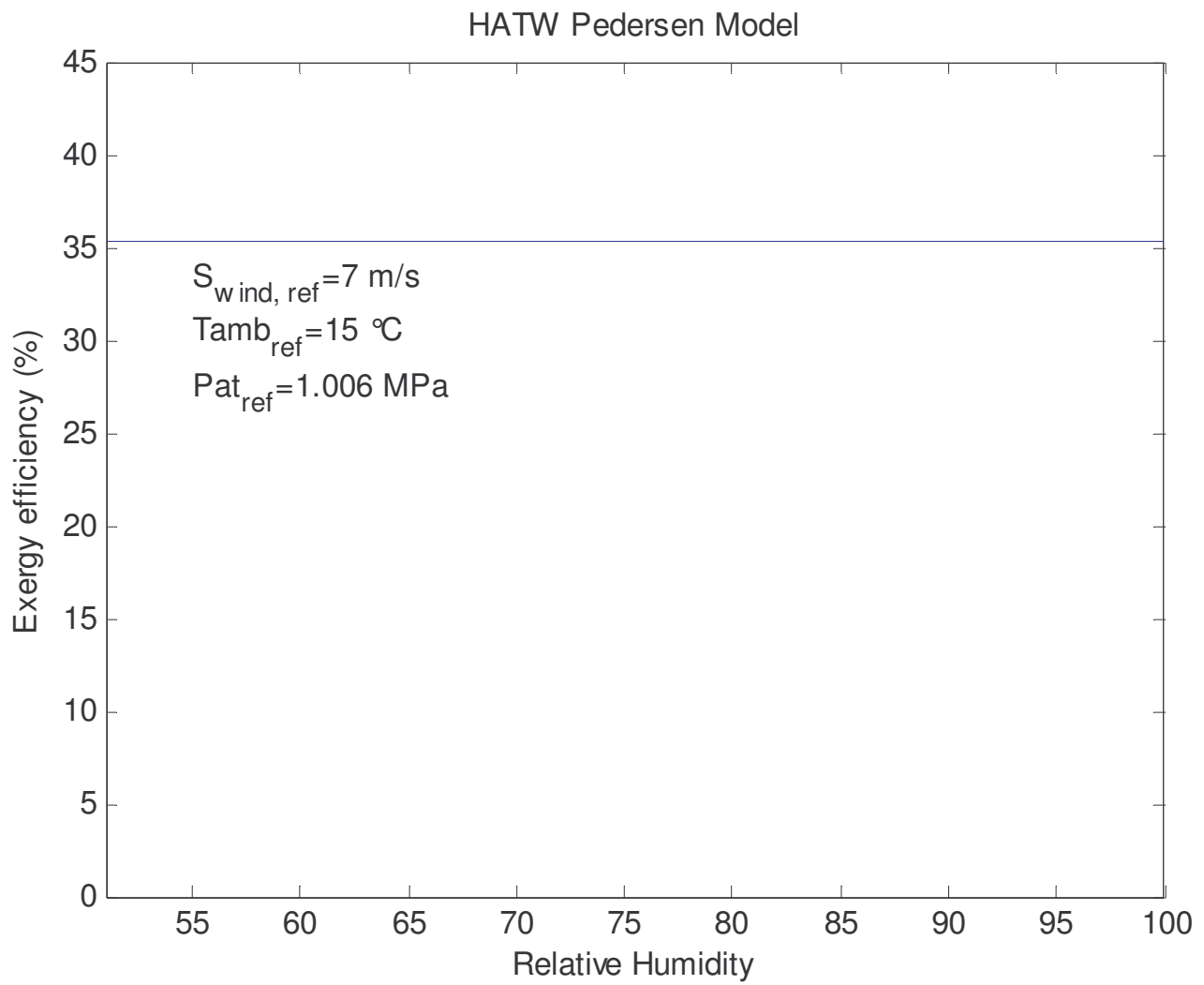

605

606

607

608

609

Figure 5 : Exergy efficiency for HATW (Pedersen's model): a) wind speed effect,

b) ambient temperature effect,

c) ambient pressure effect, and

d) relative humidity effect. 
610

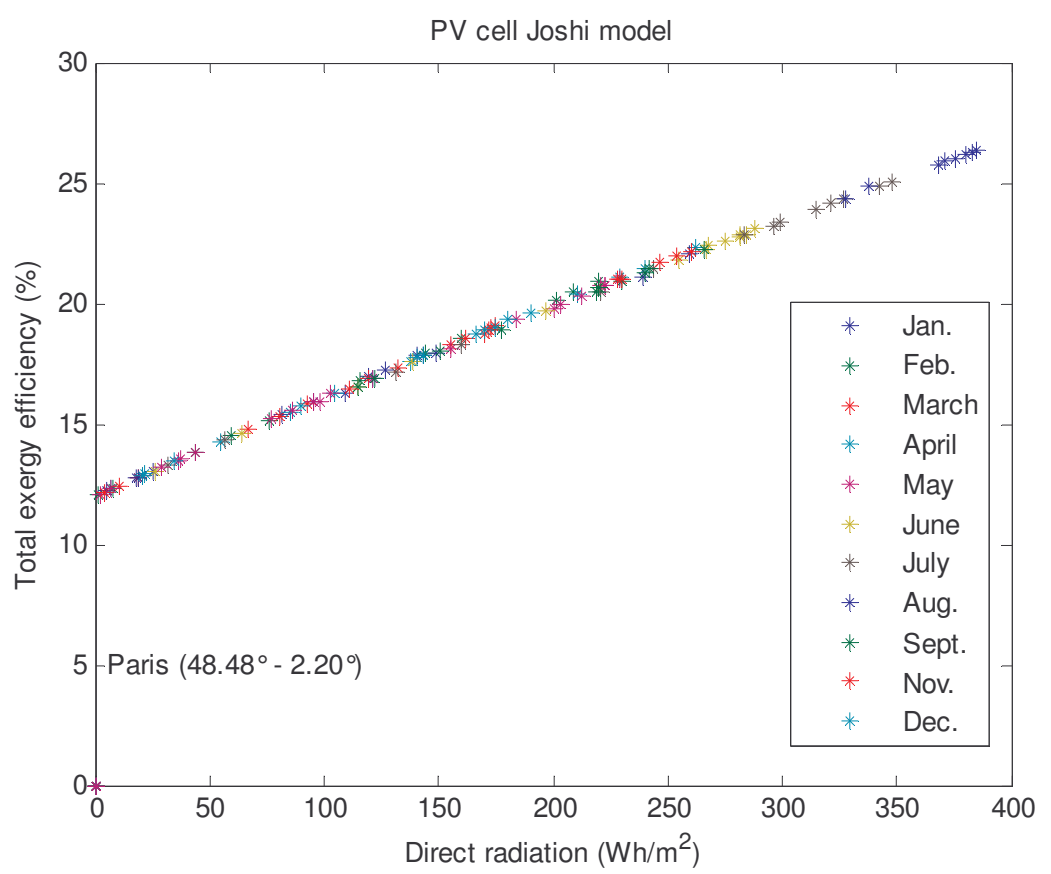

611

Figure 6 : Total exergy efficiency of PV cell versus direct radiation for Paris 


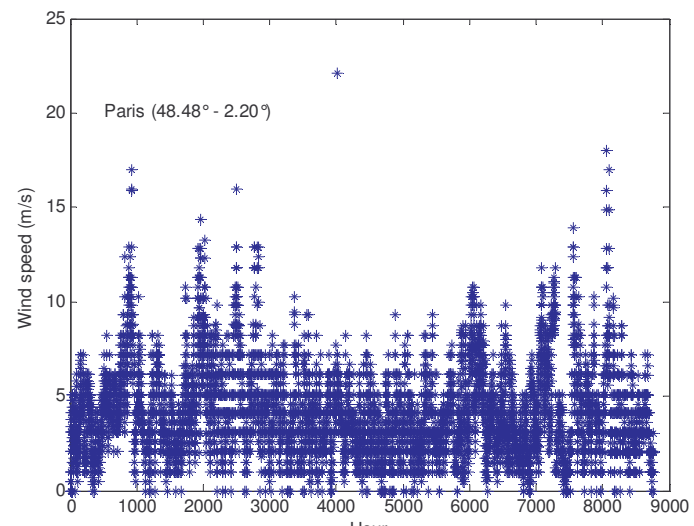

Hour

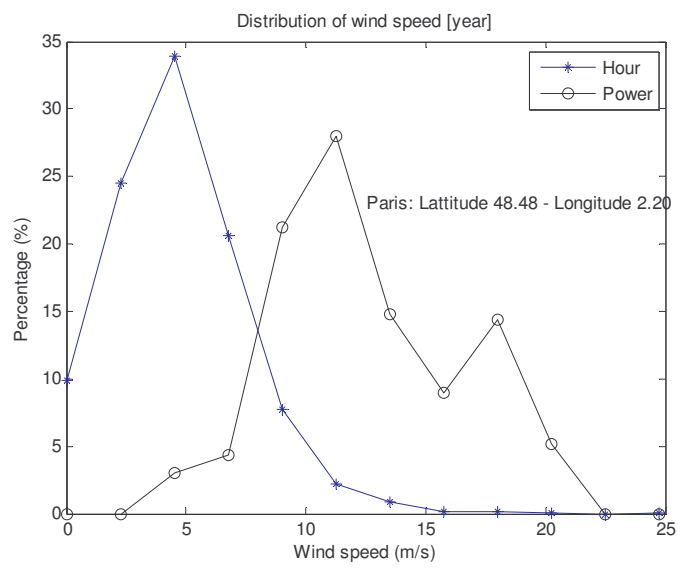

614

615

616

617

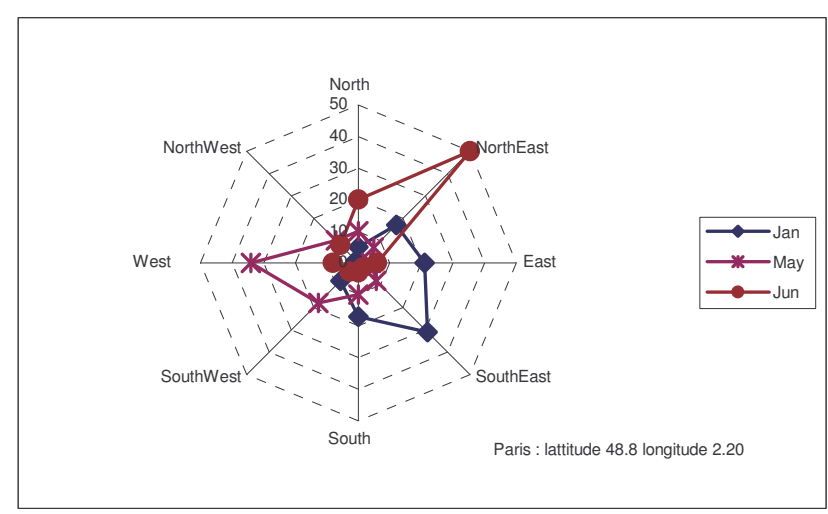

Figure 7 : a) Representative year of wind speed for Paris

b) Cumulative normal distribution of wind speed and its associated wind power for Paris c) Monthly wind direction for three months (January, May and June) for Paris 

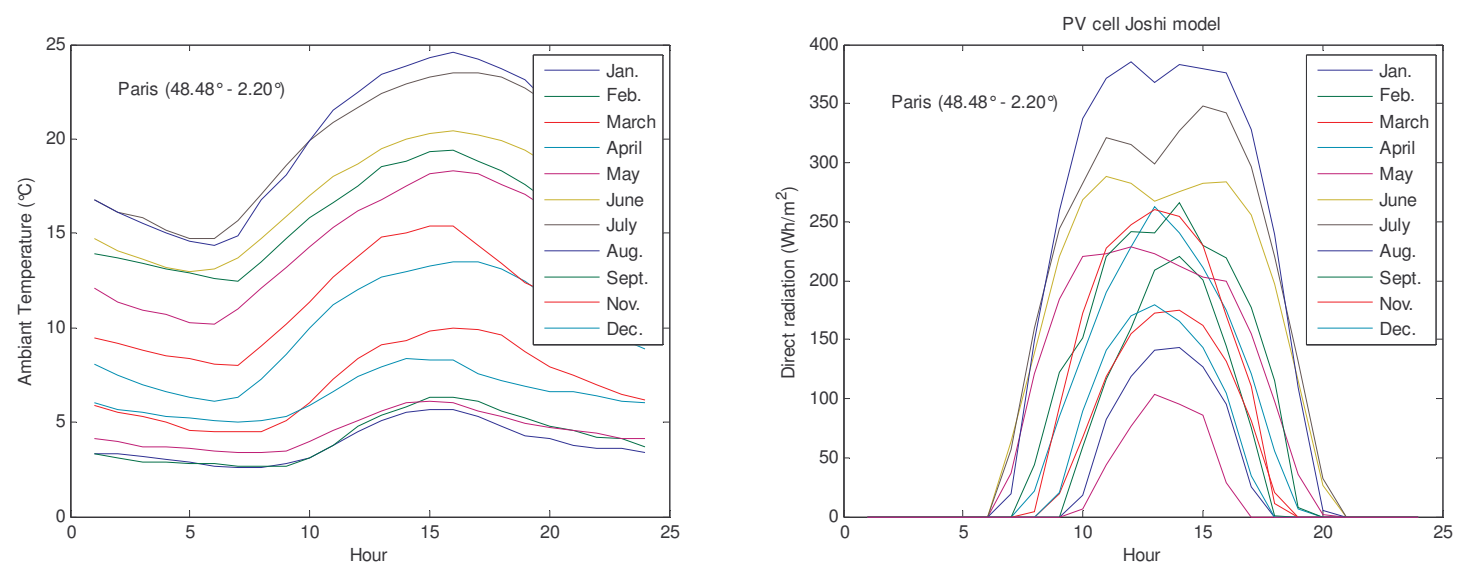

620

621

Figure 8 : a) Monthly ambient temperature at Paris

b) Monthly direct radiation at Paris 

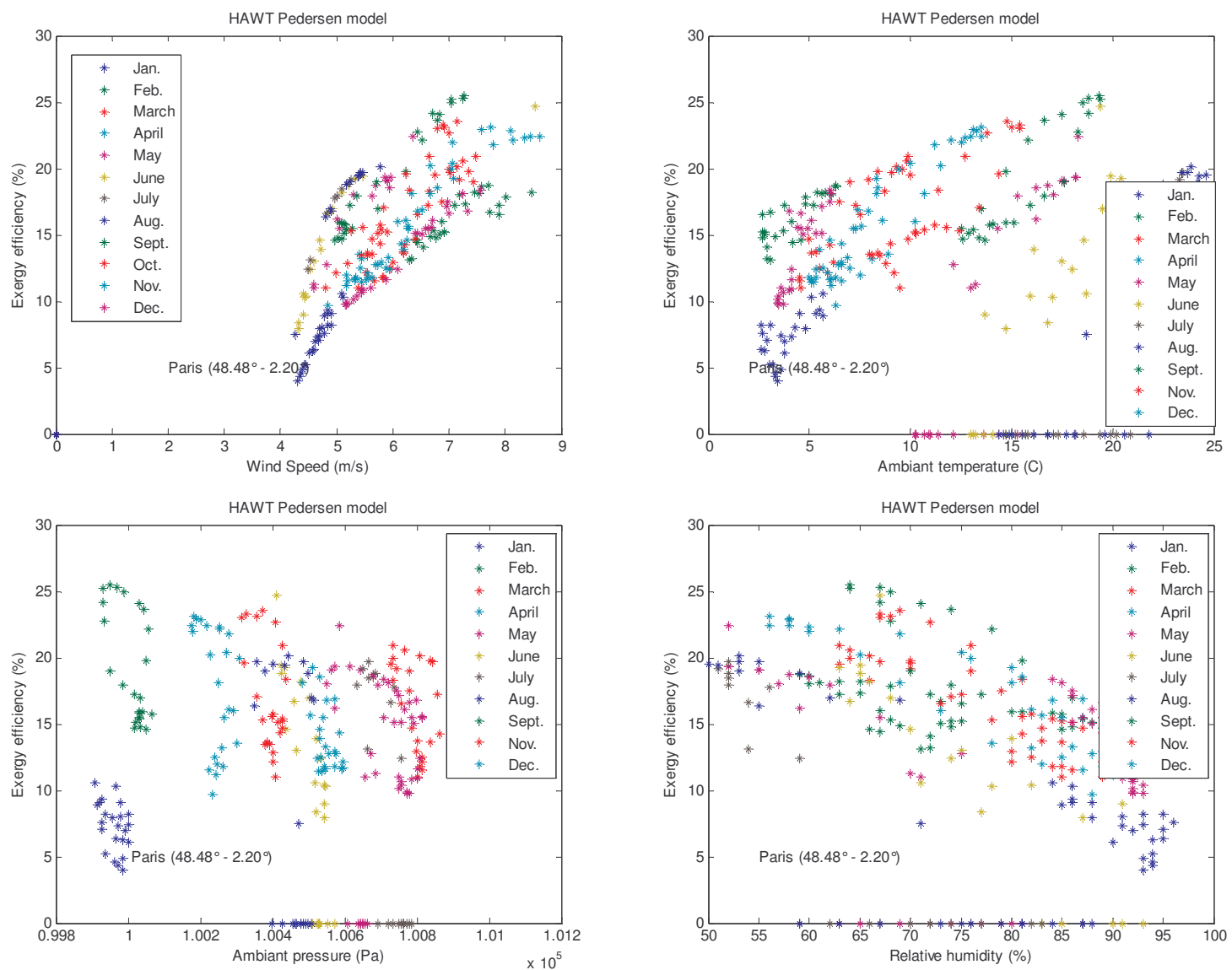

624

625

626

627

628

629

630
Figure 9: Hourly exergy efficiency of HAWT

a) versus wind speed

b) versus ambient temperature

c) versus ambient pressure

d) versus relative humidity 


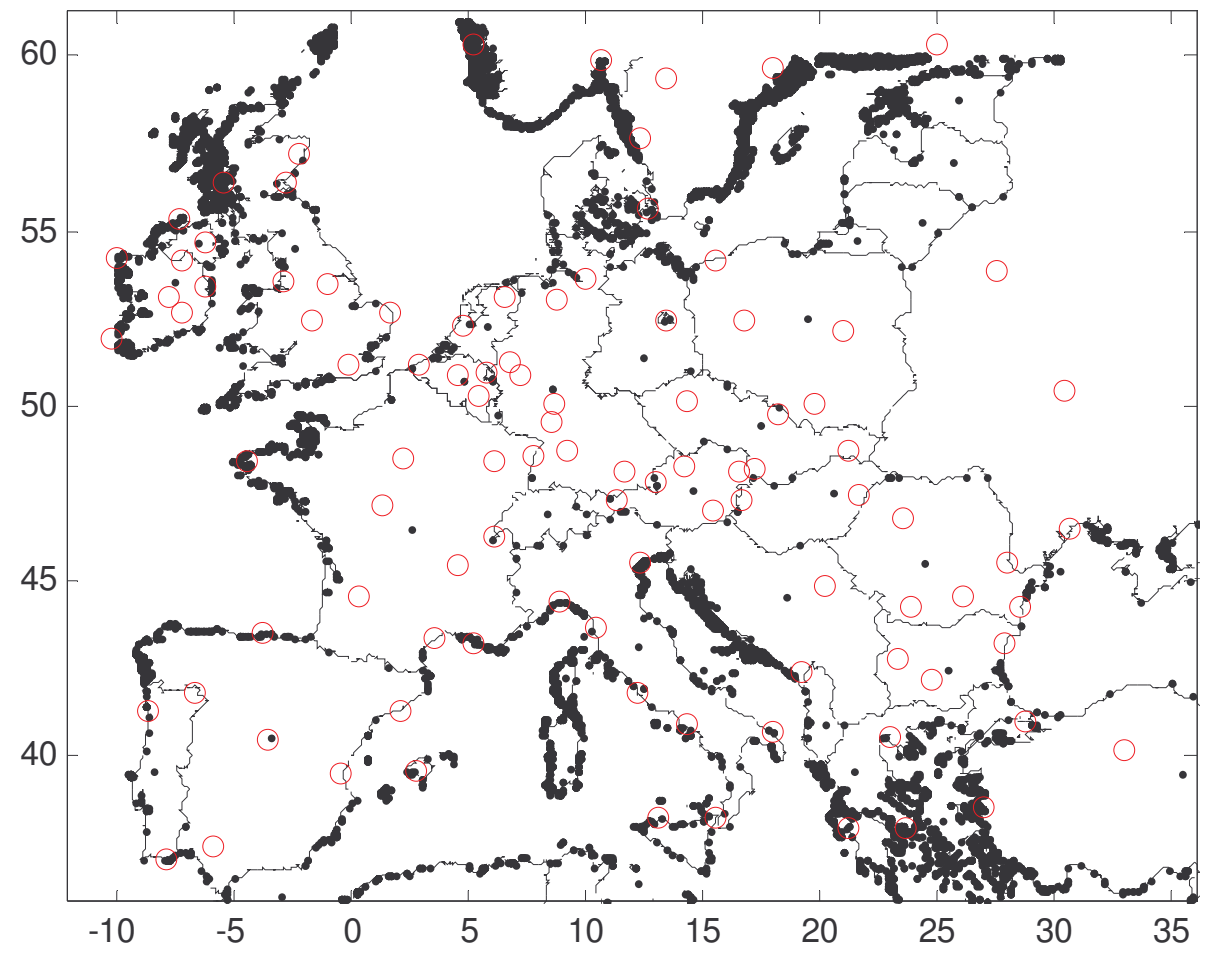

631

Figure 10: Location of meteorological stations over Europe 

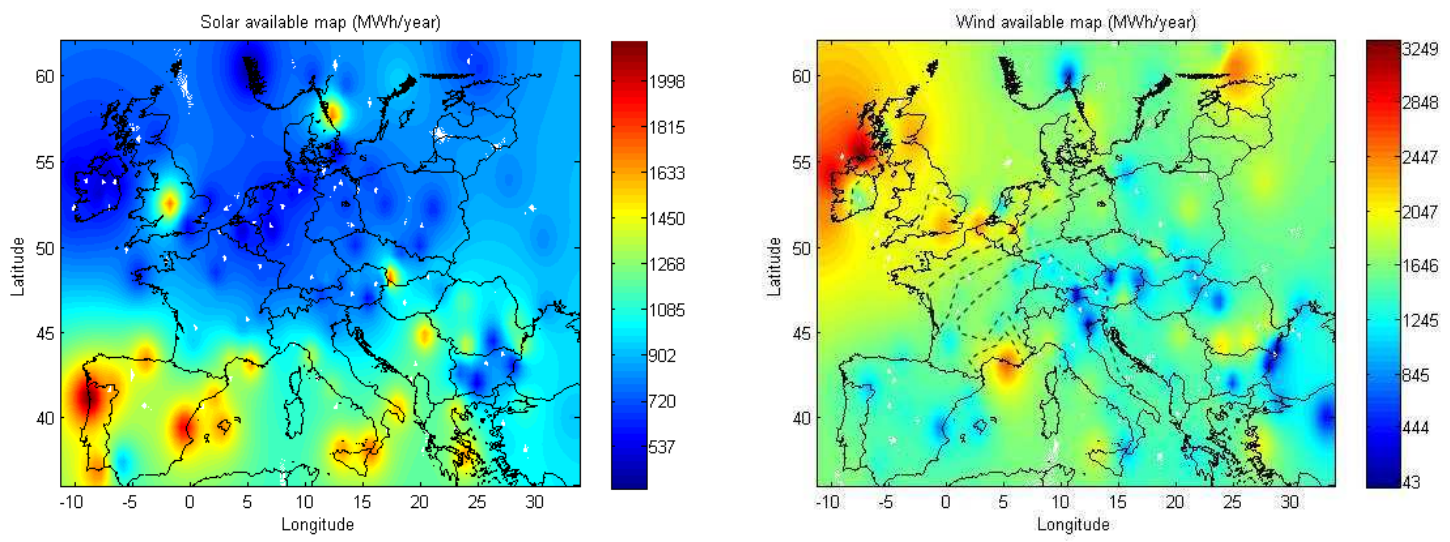

Figure 11: Primary exergy from a) sun and b) wind resources 

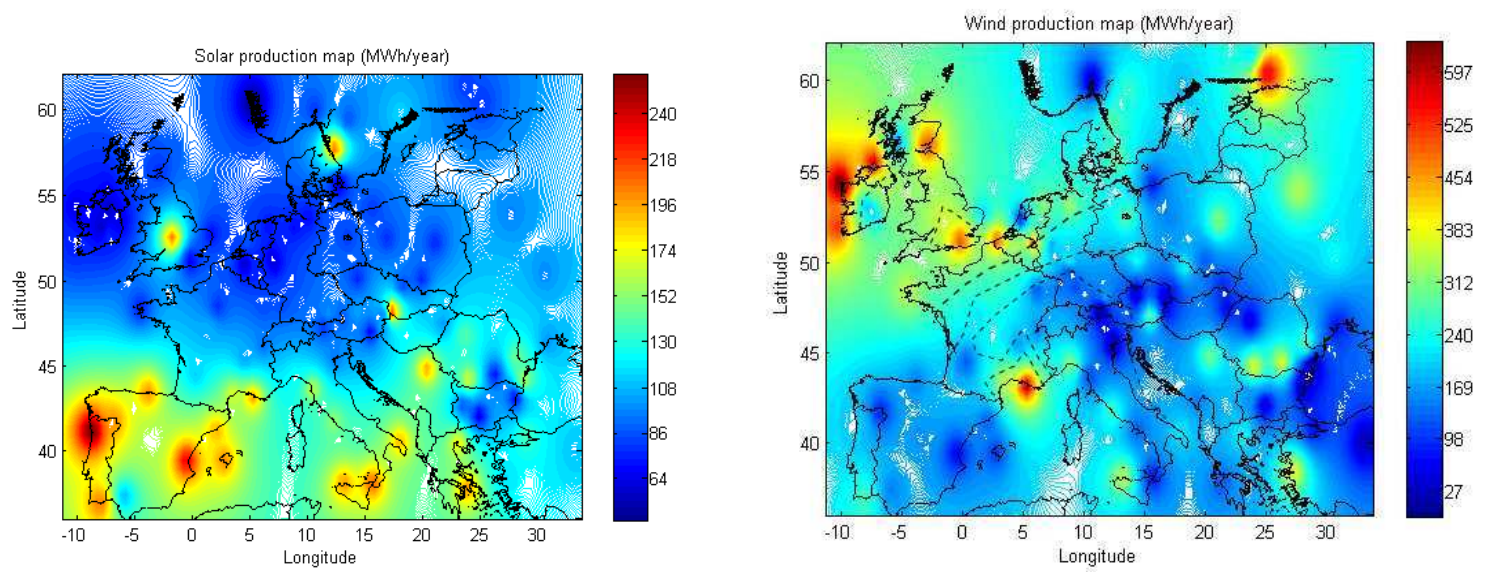

Figure 12: Yearly electric production a) solar resource b) wind resource 


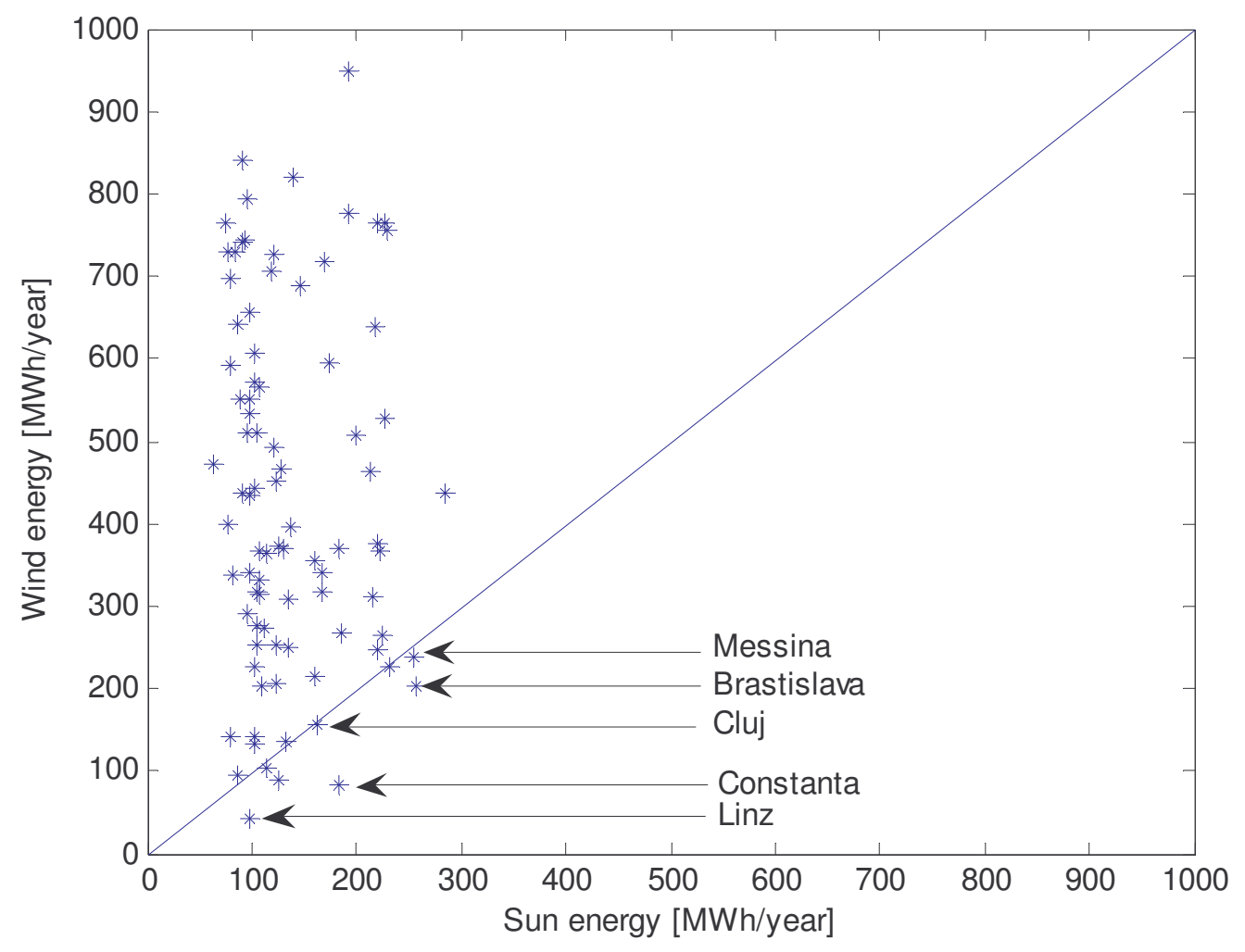

Figure 13: Wind energy potential versus sun energy potential for the 100 meteorological 639 stations tested 
640

641
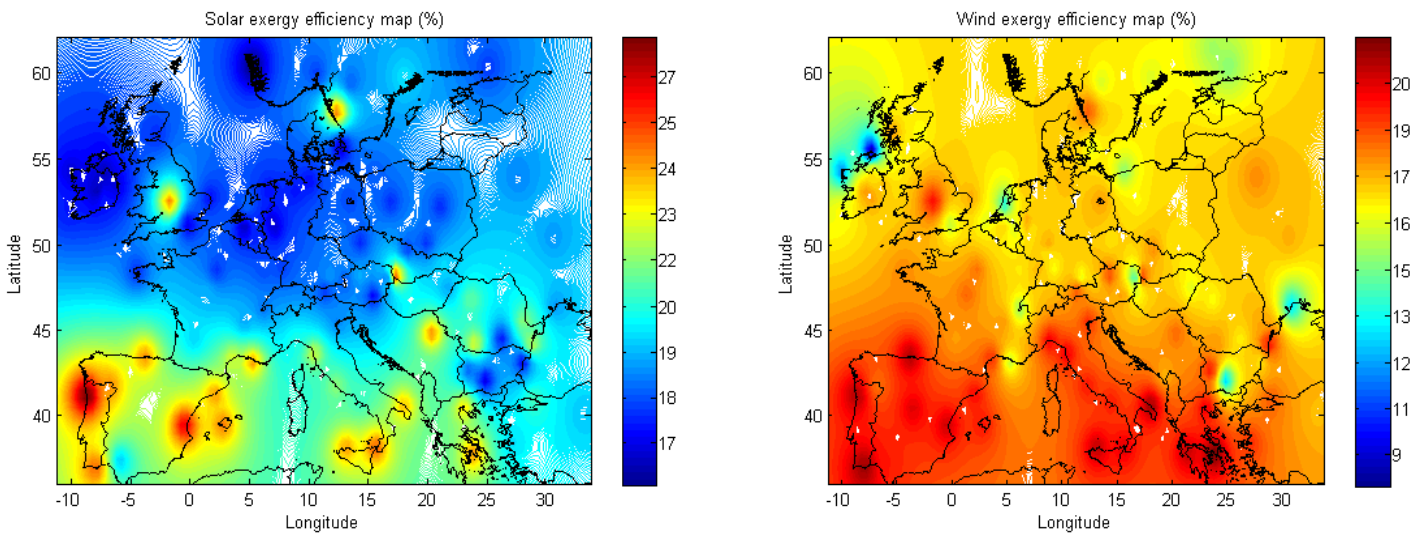

Figure 14: Yearly exergy efficiency a) solar resource b) wind resource 


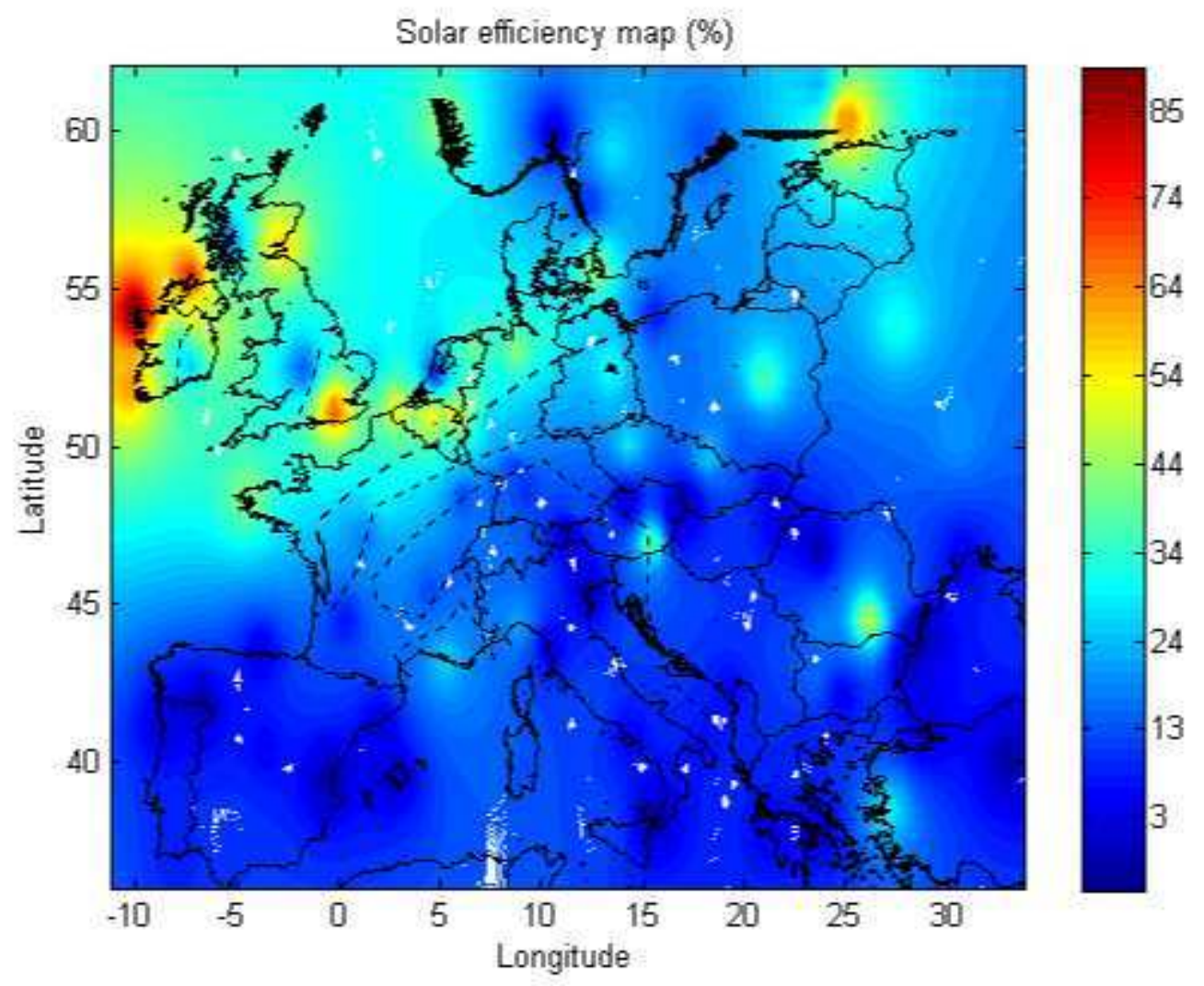

642

643

Figure 15 : Theoretical solar electric efficiency 
645 Table 1: Advantages/Drawbacks of wind turbines and PV cells

\begin{tabular}{|r|l|l|}
\hline $\begin{array}{r}\text { Renewable } \\
\text { Resources }\end{array}$ & $\begin{array}{l}\text { Areely available } \\
\text { do not generate direct pollution }\end{array}$ & $\begin{array}{l}\text { Intermittent resources: highly climate } \\
\text { dependent }\end{array}$ \\
\hline Wind Turbines & $\begin{array}{l}\text { generation and maintenance } \\
\text { are cost effective } \\
\text { Performances are still } \\
\text { improving }\end{array}$ & $\begin{array}{l}\text { need 3 times the amount of installed } \\
\text { capacity to meet demand } \\
\text { noisy } \\
\text { construction can be very expensive } \\
\text { may affect endangered species of birds }\end{array}$ \\
\hline $\begin{array}{r}\text { Photo-Voltaic } \\
\text { cells }\end{array}$ & $\begin{array}{l}\text { costs are dropping } \\
\text { performances are improving } \\
\text { extremely durable } \\
\text { cheap maintenance }\end{array}$ & $\begin{array}{l}\text { current technologies require large } \\
\text { amounts of land } \\
\text { production levels can be affected by } \\
\text { weather conditions (for example cloudy } \\
\text { and stormy days) }\end{array}$ \\
\hline
\end{tabular}

646 
647

648 Table 2 : Pressure and temperature variations

\begin{tabular}{|c|c|c|c|c|}
\hline $\begin{array}{c}\text { Wind Speed } \\
\mathrm{V} 1[\mathrm{~m} / \mathrm{s}]\end{array}$ & $\begin{array}{c}\Delta \mathrm{V}=\mathrm{V} 1-\mathrm{V} 2 \\
{[\mathrm{~m} / \mathrm{s}]}\end{array}$ & $\begin{array}{c}\Delta \mathrm{P}=\mathrm{P} 1-\mathrm{P} 2 \\
{[\mathrm{~Pa}]}\end{array}$ & $\begin{array}{c}\Delta \mathrm{T}=\mathrm{T} 2-\mathrm{T} 1 \\
\text { wind chill }[\mathrm{K}]\end{array}$ & $\begin{array}{c}\text { HATW power } \\
{[\mathrm{kW}]}\end{array}$ \\
\hline 4 & 0.4 & 11.4 & 1.4 & 2.40 \\
5 & 1.0 & 17.7 & 1.4 & 8.60 \\
6 & 1.2 & 25.5 & 1.5 & 18.80 \\
7 & 1.9 & 34.8 & 1.5 & 31.70 \\
8 & 2.2 & 45.4 & 1.5 & 44.70 \\
9 & 2.3 & 57.5 & 1.6 & 57.70 \\
10 & 2.25 & 71.0 & 1.6 & 70.60 \\
11 & 2.2 & 85.9 & 1.6 & 83.80 \\
12 & 2.1 & 102.2 & 1.6 & 97.90 \\
13 & 2.0 & 119.9 & 1.6 & 100.00 \\
\hline
\end{tabular}

649

650 